\title{
Rocuronium-induced neuromuscular block after long pretreatment of clonidine in rabbits
}

\author{
Min Seok Koo ${ }^{1}$, Nam Yun Kim ${ }^{1}$, Hee Jong Lee $^{2}$, Sung Wook Yoon ${ }^{2}$, and Kyo Sang Kim² \\ Departments of Anesthesiology and Pain Medicine, ${ }^{1}$ National Medical Center, ${ }^{2}$ College of Medicine, Hanyang University, Seoul, Korea
}

Background: Clonidine, an $\alpha-2$ adrenergic agonist, is used in the perioperative period and in intensive care for the management of hypertension. The in vivo and in vitro effects of clonidine on the actions of nondepolarizing neuromuscular blocking drugs are conflicting. We evaluated the potency and time course of rocuronium-induced neuromuscular block after prolonged pretreatment with clonidine in rabbits.

Methods: Sixty rabbits were randomly assigned to three groups; control (C) group: normal saline $0.1 \mathrm{ml} / \mathrm{kg}$ daily subcutaneous for 6 weeks; S3 group: clonidine $4 \mu \mathrm{g} / \mathrm{kg}$ daily subcutaneous for 3 weeks; S6 group: clonidine $4 \mu \mathrm{g} / \mathrm{kg}$ daily subcutaneous for 6 weeks. The dose-response relations of rocuronium were tested in 30 rabbits (10 from each of the three groups) during ketamine-thiopental anesthesia, while the time course of rocuronium $0.6 \mathrm{mg} / \mathrm{kg}$ was examined in 10 rabbits each from the three groups.

Results: There was no difference in mean arterial pressure and pulse rate among the experimental groups. The calculated $\mathrm{ED}_{50}$ for rocuronium decreased significantly from $64.1 \mu \mathrm{g} / \mathrm{kg}$ (C group) to $50.3 \mu \mathrm{g} / \mathrm{kg}$ (S3 group) and 47.8 $\mu \mathrm{g} / \mathrm{kg}$ (S6 group) $(\mathrm{P}<0.001)$. There was no difference in the onset and the recovery times after rocuronium.

Conclusions: Rocuronium after pretreatment with clonidine for three or six weeks may have an increased effect, but no difference in the duration of action compared with control group. (Korean J Anesthesiol 2010; 59: 190-195)

Key Words: Clonidine, Pharmacodynamics, Rabbits, Rocuronium.

Received: May 27, 2010. Accepted: June 1, 2010.

Corresponding author: Kyo Sang Kim, M.D., Department of Anesthesiology and Pain Medicine, College of Medicine, Hanyang University, 17, Haengdang-dong, Seongdong-gu, Seoul 133-792, Korea. Tel: 82-2-2290-8680, Fax: 82-2-2299-8692, E-mail: kimks@hanyang.ac.kr Presented in part at 86th the Korean Society of Anesthesiologists Annual Meeting, Jeju, November 6, 2009.

This is a theisis for a doctor's degree.

(c) This is an open-access article distributed under the terms of the Creative Commons Attribution Non-Commercial License (http:// creativecommons.org/licenses/by-nc/3.0/), which permits unrestricted non-commercial use, distribution, and reproduction in any medium, provided the original work is properly cited. 


\section{Introduction}

Clonidine (Catapres ${ }^{\circledR}$, Boehringer Ingelheim Pharmaceuticals, Inc. U.S.A.), an $\alpha-2$ adrenergic agonist, has been used in management of hypertension for more than 35 years and is administered as a long-term infusion during surgery to prevent myocardial ischemia [1]. Due to its sedative and analgesic effects, preoperative administration of clonidine reduces opioid or anesthetic requirements and anxiety [2], to stabilize excessive changes in blood pressure and pulse rate resulting from pain from tracheal intubation and surgery by inhibiting sympathetic reactions, and also to increase skin temperature [3]. The interaction of clonidine and nondepolarizing muscle relaxants is unclear: oral clonidine enhances vecuronium-induced muscle relaxation in one study [4], but not in others [5]. Clonidine does not increase acetylcholine release from the neuromuscular junction and does not enhance neuromuscular contraction in vitro [6]. In nerve-hemidiaphragm models, clonidine does not influence d-tubocurarine-induced spasmolysis [7], while high concentrations of clonidine enhance rocuronium-induced muscle relaxation [8]. Consequently, we have conflicting results from both in vivo and in vitro experiments on the effects of clonidine [4-8].

Rocuronium bromide (rocuronium) (Esmeron ${ }^{\circledR}$, Korean Organon Inc., Seoul, Korea) is a steroidal nondepolarizing muscle relaxant frequently used in modern anesthesia, with a more rapid onset than conventional nondepolarizing muscle relaxants and an intermediate duration of action similar to vecuronium [9].

To date, all interactions between clonidine and muscle relaxants have been based on results of preoperative administration of clonidine for a few hours, whereas clinical practices require longer administration. We used rabbits to test whether long-term administration of clonidine would affect rocuroniuminduced muscle relaxation.

\section{Materials and Methods}

The study was approved by the Animal Care and Use Committee of our hospital. Adult male rabbits (weighing $2-3 \mathrm{~kg}, \mathrm{n}$ $=60$ ) were randomly assigned to three groups (20 each). The control (C) group received one subcutaneous injection of 0.1 $\mathrm{ml} / \mathrm{kg}$ normal saline daily for 6 weeks on the opposite hip of the experimental region. The S3 group received $4 \mu \mathrm{g} / \mathrm{kg}$ clonidine daily subcutaneously for 3 weeks. The S6 group received 4 $\mu \mathrm{g} / \mathrm{kg}$ clonidine daily subcutaneously for 6 weeks. Clonidine doses were determined by weighing rabbits before each administration.

For pre-treatment, anesthesia was induced by a subcutaneous injection of $10-15 \mathrm{mg} / \mathrm{kg}$ ketamine (Ketara ${ }^{\circledR}$, Yuhan Corp.,
Seoul, Korea) and the intravenous route was secured by a $22-\mathrm{G}$ catheter, through which $0.9 \%$ of saline solution was provided at $6 \mathrm{ml} / \mathrm{kg} / \mathrm{h}$ using an infusion pump (STC 523, Terumo Co., Tokyo, Japan). After intravenous injection of $5 \mathrm{mg} / \mathrm{kg}$ thiopental sodium (Pentotalsodium ${ }^{\circledR}$, Choongwae Pharma Corp., Korea), tracheotomy was performed and an endotracheal tube (ID = $2.5-3.0 \mathrm{~mm}$ ) was inserted and attached to an animal ventilator (SN-480-5, Shinano Co., Tokyo, Japan). Controlled respiration was performed with $\mathrm{PETCO}_{2}$ at $30-35 \mathrm{mmHg}$ using an $\mathrm{ETCO}_{2} /$ $\mathrm{SpO}_{2}$ monitor $\left(\mathrm{CO}_{2} \mathrm{SMO}^{\circledR}\right.$, Novametrix Co., Wallingford, CT, USA), while tidal volume (TV) was set at $25 \mathrm{ml} / \mathrm{kg}$; tidal rate (TR), 30-35 breath/min; inspiration time : expiration time (I : E) ratio $=1: 2$. Arterial blood gas analysis (ABGA) was intermittently performed using GEM-STAT ${ }^{\circledR}$ gas analyzer (Mallinckrodt Co., Ann Arbor, MI, USA). For continuous management of anesthesia, thiopental sodium was infused by an infusion pump at the rate of $26 \mathrm{mg} / \mathrm{kg} / \mathrm{h}$.

Rectal temperature was kept at $38^{\circ} \mathrm{C}$ using a thermostat (Blanketrol II, 222, Cincinnati Sub-Zero Co., Cincinnati, OH, USA) and a heat lamp. After catheterization of a 22-G catheter into the right common carotid artery, a monitoring system (SpaceLabs ${ }^{\circledR}$, 90603A $^{\circledR}$, SpaceLabs Co., Redmond, WA, USA) was established to measure arterial pressure and ECG. At 20 minutes after all manipulations were completed, which was required for stabilizing the animals, the mean arterial pressure and pulse were measured 10 minutes before and after each administration of muscle relaxants.

To sample neuromuscular specimens, the anterior tibial muscle was removed and exposed and its distal part was dissected, cut off, and the isolated strip was suspended at the tendon from a force displacement transducer $\left(45196 A^{\circledR}\right.$, Sanei Co., Tokyo, Japan) using a 3-0 silk suture connected to a physiologic recording device (Biophysiograph $7748^{\circledR}$, San-ei Co, Japan) for continuous recording of myospasm. After the samesided femoral region and the distal part of the anterior tibia were fixed, resting tension was maintained at the anterior tibial muscle with a preload of $20 \mathrm{~g}$.

The common peroneal nerve was exposed out of the left upper knee joint, dissected, and positioned on wire bipolar electrodes. The twitch response at the anterior tibial muscle was elicited by a train-of-four (TOF) supramaximal squarewave stimuli for 0.2 milliseconds (ms) every 10 second (s) using a peripheral nerve stimulator (DualStim ${ }^{\circledR}$, Life-Tech Inc., Houston, TX, USA), and the lengths/intervals of the first twitch $\left(\mathrm{T}_{1}\right)$ from TOF stimulation were compared.

\section{Experiment I}

Thirty rabbits were divided into three groups with 10 rabbits each. To maintain animal stability, the lengths/intervals of 
control twitch were measured with continuous TOF stimulation at $10 \mathrm{~s}$ intervals $20 \mathrm{~min}$ after all manipulations were completed. For Group S3 and S6, an intravenous dose of rocuronium 40, 60, and $80 \mu \mathrm{g} / \mathrm{kg}$ was injected, with 40,80 and $120 \mu \mathrm{g} / \mathrm{kg}$ infused in Group C. Neuromuscular block was quantified by the first twitch (T1) of the TOF. To obtain dose-response curves, the suppression ratio of $\mathrm{T} 1$ was expressed in probit coordinates, the amount in logarithm coordinates, while rocuronium, having an intermediate duration of action, was tested using the single-dose method [9] using doses determined during a pilot study. The comparison of the dose-response curves was made using analysis of covariance (ANCOVA), and the effective doses $\left(\mathrm{ED}_{50}, \mathrm{ED}_{95}\right)$ at the time of $50 \%$ and $95 \%$ of twitch suppression were calculated. All muscle relaxants were intravenously injected within $<5 \mathrm{~s}$. The next dose of medication was provided after at least 2 -fold longer wait than the duration of action of the previous administration following full recovery. After completion of the experiment, the rabbits were given a lethal dose of thiopental sodium and potassium chloride by intravenous injection.

\section{Experiment II}

We used 30 rabbits (10 from each group) in this experiment. For each group, $0.6 \mathrm{mg} / \mathrm{kg}$ rocuronium was intravenously infused and the inhibition and recovery of twitch were recorded and observed during spontaneous recovery. The twitch recordings were evaluated for the following variables: time from end of injection of rocuronium to maximal twitch suppression (onset); time from end of injection of the initial dose to recovery of $\mathrm{T} 1$ in the $\mathrm{TOF}$ to the recurrence and a value of $25 \%, 75 \%$, and $95 \%$ of control twitch tension (T1[1, 25, 75, 95]); time from $25 \%$ to $75 \%$ twitch recovery (recovery index; RI); time from end of injection of the initial dose to a TOF ratio (T4/T1) of $70 \%$ (TOF(70)). At the end of the experiments, animals were given a lethal dose of thiopental sodium and potassium chloride by intravenous injection.

Table 1. Dose-Response Data of Rocuronium in Rabbits after Clonidine $4 \mu \mathrm{g} / \mathrm{kg}$ Daily Subcutaneous Injection for 3 or 6 Weeks

\begin{tabular}{lccc}
\hline & $\begin{array}{c}\text { Group C } \\
(\mathrm{n}=10)\end{array}$ & $\begin{array}{c}\text { Group S3 } \\
(\mathrm{n}=10)\end{array}$ & $\begin{array}{c}\text { Group S6 } \\
(\mathrm{n}=10)\end{array}$ \\
\hline $\mathrm{ED}_{25}(\mu \mathrm{g} / \mathrm{kg})$ & $52.5 \pm 5.1$ & $39.7 \pm 4.7^{*}$ & $39.4 \pm 4.5^{*}$ \\
$\mathrm{ED}_{50}(\mu \mathrm{g} / \mathrm{kg})$ & $64.1 \pm 7.8$ & $50.3 \pm 6.7^{*}$ & $47.8 \pm 6.5^{*}$ \\
$\mathrm{ED}_{95}(\mu \mathrm{g} / \mathrm{kg})$ & $98.3 \pm 12.5$ & $75.8 \pm 9.7^{*}$ & $66.5 \pm 8.6^{*}$ \\
Slope $(\mathrm{probit} / \mathrm{log})$ & $4.7 \pm 1.1$ & $4.3 \pm 0.9$ & $5.4 \pm 1.4$ \\
\hline
\end{tabular}

Data are expressed as mean \pm SD. Group C: control group, Group S3: after Clonidine $4 \mu \mathrm{g} / \mathrm{kg}$ daily sq for 3 weeks, Group S6: after Clonidine $4 \mu \mathrm{g} / \mathrm{kg}$ daily sq for 6 weeks. $\mathrm{ED}_{50}: 50 \%$ effective dose, $\mathrm{ED}_{95}: 95 \%$ effective dose, $* \mathrm{P}<0.001$ compared with the control group.

\section{Statistics}

Statistical analyses were performed using SPSS (version 17.0, SPSS Inc, Chicago, USA), and statistical evaluations of slope at $\mathrm{ED}_{50}$ and $\mathrm{ED}_{95}$ were confirmed by linear regression analysis and analysis of covariance (ANCOVA). Pharmocodynamic effects were confirmed by one way analysis of variance (ANOVA), whereas differences between the groups were evaluated by Bonferroni multiple range t-test. All data are expressed as mean $\pm \mathrm{SD}$, and $\mathrm{P}<0.05$ was accepted as statistically significant.

\section{Results}

The mean arterial blood pressures of Group C, S3, and S6 were $77.4 \pm 11.3 \mathrm{mmHg}, 70.4 \pm 10.5 \mathrm{mmHg}$, and $71.5 \pm 10.8$ $\mathrm{mmHg}$, respectively; S3 and S6 were lower than group C. Pulse rates were similar in all groups, although Groups S3 and S6 were lower than Group C: Group C, $280.4 \pm 19.3$ beats/min; Group S3, $268.9 \pm 16.6$ beats/min; Group S6, $271.4 \pm 17.8$ beats $/ \mathrm{min}$.

The $\mathrm{ED}_{50}$ of rocuronium was $64.1 \pm 7.8 \mu \mathrm{g} / \mathrm{kg}$ for Group C, 50.3 $\pm 6.7 \mu \mathrm{g} / \mathrm{kg}$ for Group S3, and $47.8 \pm 6.5 \mu \mathrm{g} / \mathrm{kg}$ for S6. The $\mathrm{ED}_{95}$ of rocuronium were $98.3 \pm 12.5 \mu \mathrm{g} / \mathrm{kg}, 75.8 \pm 9.7 \mu \mathrm{g} / \mathrm{kg}$, and $66.5 \pm$ $8.6 \mu \mathrm{g} / \mathrm{kg}$, respectively, with significant decreases in Group S3 and $\mathrm{S} 6$ versus Group C $(\mathrm{P}<0.001)$ (Table 1). The dose-response curve was shifted significantly leftward in Group S3 and S6 (P < 0.001) compared with Group C, but the slopes were similar: 4.7 $\pm 1.1,4.3 \pm 0.9$, and $5.4 \pm 1.4$, respectively (Table 1, Fig. 1).

The onset times for Group C, S3 and S6 were $0.4 \pm 0.2 \mathrm{~min}$, $0.4 \pm 0.1 \mathrm{~min}$, and $0.3 \pm 0.1 \mathrm{~min}$, respectively. The time from the end of rocuronium injection until the reappearance of $\mathrm{T} 1$ was similar: $13.5 \pm 1.7 \mathrm{~min}, 14.2 \pm 1.7 \mathrm{~min}$, and $15.1 \pm 1.9 \mathrm{~min}$,

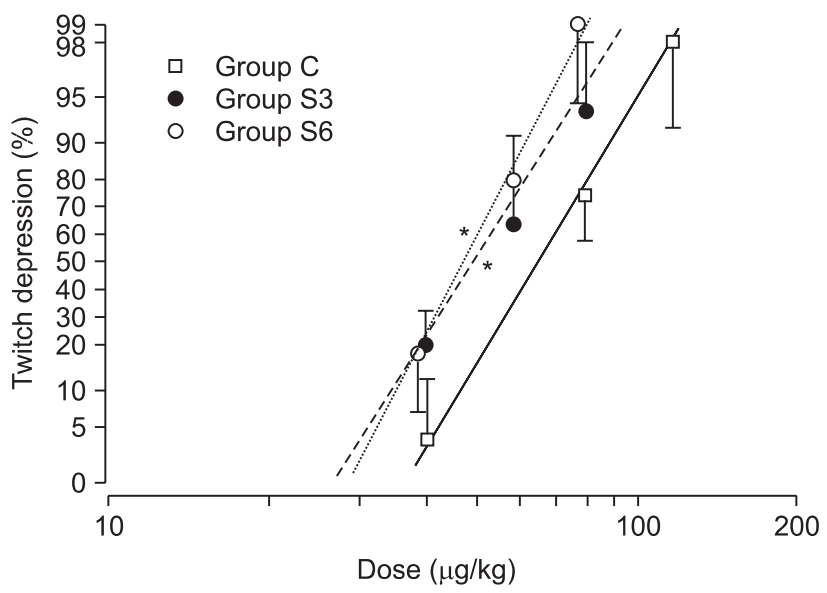

Fig. 1. Dose-response curves of rocuronium obtained by log dose-probit linear regression for twitch depression after chronic pretreatment with clonidine in rabbits. Individual points represent mean (95\% confidence intervals) twitch depression (\% control) with each dose. ${ }^{*} \mathrm{P}<0.001$ compared with control values. 
Table 2. Onset and Recovery Times (min) in Rabbits given Rocuronium $0.6 \mathrm{mg} / \mathrm{kg}$ after Clonidine $4 \mu \mathrm{g} / \mathrm{kg}$ Daily Subcutaneous Injection for 3 or 6 Weeks

\begin{tabular}{lccccccc}
\hline & Onset & T1 (1) & T1 (25) & T1 (75) & T1 (95) & RI & TOF (70) \\
\hline Group C $(\mathrm{n}=10)$ & $0.4 \pm 0.2$ & $13.5 \pm 1.7$ & $16.4 \pm 2.4$ & $20.2 \pm 2.9$ & $22.6 \pm 3.1$ & $3.8 \pm 0.7$ & $24.1 \pm 3.4$ \\
Group S3 (n=10) & $0.4 \pm 0.1$ & $14.2 \pm 1.7$ & $16.1 \pm 2.2$ & $20.4 \pm 2.7$ & $22.8 \pm 2.9$ & $4.3 \pm 0.8$ & $24.5 \pm 3.1$ \\
Group S6 (n=10) & $0.3 \pm 0.1$ & $15.1 \pm 1.9$ & $15.6 \pm 2.1$ & $19.4 \pm 2.6$ & $21.3 \pm 2.8$ & $3.8 \pm 0.7$ & $23.9 \pm 2.9$ \\
\hline
\end{tabular}

Data are expressed as mean \pm SD. Onset: the time from injection of rocuronium to $100 \%$ twitch depression, $\mathrm{T} 1(1,25,75$ and 95$)$ : the time from injection to recurrence, $25 \%, 75 \%$ and $95 \%$ recovery of first twitch of TOF (T1), respectively, RI: recovery index from to TOF $25 \%$ to $75 \%$ recovery of T1, TOF (70): the time from injection ratio (T4/T1) of 70\%. Group C: control group, Group S3: after Clonidine $4 \mu \mathrm{g} / \mathrm{kg}$ daily sq for 3 weeks, Group S6: after Clonidine $4 \mu \mathrm{g} / \mathrm{kg}$ daily sq for 6 weeks.

respectively (Table 2 ). The times of $95 \%$ recovery of $\mathrm{T} 1$ were 22.6 $\pm 3.1 \mathrm{~min}, 22.8 \pm 2.9 \mathrm{~min}$, and $21.3 \pm 2.8 \mathrm{~min}$, and the recovery times of the TOF ratio to $70 \%$ were $24.1 \pm 3.4 \mathrm{~min}, 24.5 \pm 3.1 \mathrm{~min}$, and $23.9 \pm 2.9 \mathrm{~min}$, respectively, for Group C, S3, and S6 (Table 2). No differences were noted in the recovery index $(25-75 \%)$ of Group C, S3, and S6: $3.8 \pm 0.7 \mathrm{~min}, 4.3 \pm 0.8 \mathrm{~min}$, and $3.8 \pm 0.7$ min, respectively.

\section{Discussion}

Clonidine, $4 \mu \mathrm{g} / \mathrm{kg}$ daily subcutaneous injection, for 3 or 6 weeks significantly left-shifted the dose-response curve of rocuronium but did not change the onset and recovery times after intravenous injection of rocuronium $(0.6 \mathrm{mg} / \mathrm{kg})$, although mean arterial pressure and pulse rate tended to decline.

Clonidine is a direct-acting $\alpha-2$ adrenergic receptor agonist (an imidazole derivative) with more affinity for $\alpha-2$ than $\alpha-1$ adrenergic receptors, acting on sympathetic preganglionic neurons to suppress the effects of norepinephrine or phenylephrine on $\alpha-1$ vasoconstriction and allows blood vessels to relax [10]. Intravenous administration of clonidine $(5 \mu \mathrm{g} / \mathrm{kg}) 10 \mathrm{~min}$ before anesthetic induction in human adults reduced endotracheal intubation-induced increases in blood pressure (BP) and pulse rates [11], while a pre-anesthetic injection of clonidine $(0.2 \mathrm{mg})$ into muscle reduced systolic BP caused by strong stimuli such as endotracheal intubation, but had no effects on diastolic BP and pulse rates [12]. In laparoscopic cholecystectomy, intravenous administration of $0.15 \mathrm{mg}$ clonidine for $10 \mathrm{~min}$ after the start of operation suppresses increases in BP and pulse rates during surgery [13]. Long-term administration of clonidine in patients with serious hypertension also slightly reduced BP and pulse rates, but did not influence cardiac output, blood flow rate, renal plasma flow, and glomerular filtration rate (GFR) [14]. Longterm administration of clonidine in rats reduced $\mathrm{BP}$ and pulse rate for the first two days, but thereafter did not change BP and pulse [15], perhaps due to clonidine tolerance [16]. Here clonidine showed a tendency to reduce BP and pulse rates. The clinical dose of $4 \mu \mathrm{g} / \mathrm{kg} /$ day is not excessive but leads to central sympathetic block by long-term stimulation of $\alpha$-2 adrenergic receptors that is offset by peripheral vasoconstriction [17]. The similarities in 3-week and 6-week treatments probably resulted from a decrease in the threshold and sensitivity of the arterial baroreceptor reflex due to long-term administration of clonidine [18].

In a human trial, oral administration of clonidine $4-5.5 \mu \mathrm{g} /$ $\mathrm{kg} 90$ min before anesthetic induction increased the duration of muscle relaxation produced by $0.1 \mathrm{mg} / \mathrm{kg}$ vecuronium by of $26.4 \%$ [4]. However, the study used isoflurane as an inhalation anesthetic on only 8 subjects; the small sample size and interactions with inhalation anesthetics should be considered. A different study of oral clonidine $5 \mu \mathrm{g} / \mathrm{kg} 90 \mathrm{~min}$ before anesthetic induction in humans did not influence the duration of muscle relaxation produced by $0.1 \mathrm{mg} / \mathrm{kg}$ vecuronium in 21 subjects and not using inhalation anesthetics [5]. We also did not find clonidine-induced alterations in the duration of neuromuscular blockade. In a study using a nerve-hemidiaphragm model, clonidine $50 \mu \mathrm{M}$ induced leftward shifts in rocuronium doseresponse curves [8]. We also found dose-response curves for rocuronium that shifted leftward, indicating enhancement of rocuronium-induced muscle relaxation, in contrast to previous results that clonidine does not affect muscle relaxants [7]. Clonidine, which suppresses both plasma catecholamine and acetylcholine [19], induces leftward shifts of rocuronium dose-response curves as in the present study. Because shifts in the rocuronium dose-response curves were not blocked by yohimbine ( $\alpha-2$ adrenergic receptor blocker) and a small dose of clonidine did not shift the dose-response curves, rocuronium curve shifts are not induced by $\alpha-2$ adrenergic receptors [8]. Catecholamine (norepinephrine and epinephrine) given intra-arterially or intravenously administered to stimulate $\alpha-1$ adrenergic receptors, enhanced the release of acetylcholine in skeletal muscle, neuromuscular transmission was accelerated, and d-tubocurarine-induced muscle relaxation was antagonized [20]. Stimulation of $\alpha-2$ adrenergic receptors in the central nervous system (CNS) depresses the release of catecholamine and acetylcholine and increases the effects of nondepolarizing muscle relaxants [21], consistent with the results of the present 
study but counter to the reports that the release of acetylcholine is not relevant to $\alpha-2$ adrenergic receptors. Clonidine acts weakly on $\alpha$-1 adrenergic receptors, but this interaction does not mediate the enhancement of muscle relaxation produced by rocuronium. Stimulation of $\alpha-1$ adrenergic receptors boosts the release of acetylcholine [22] and may stop the reversal of rocuronium's muscle relaxation effects. Leftward shifts of the dose-response curves in nondepolarizing muscle relaxants are elicited by dexmedetomidine ( $\alpha-2$ adrenergic receptor stimulant, an imidazole) or etomidate, which competitively or noncompetitively blocks nicotinic acetylcholine receptors [23] and clonidine also blocks nicotinic acetylcholine receptors [8].

The $\mathrm{ED}_{50}$ and $\mathrm{ED}_{95}$ of rocuronium in rabbits were $61.5 \pm 5.3$ $\mu \mathrm{g} / \mathrm{kg}$ and $95.1 \pm 6.7 \mu \mathrm{g} / \mathrm{kg}$, respectively [24], and Kim et al. [25] argued that $\mathrm{ED}_{50}$ value of $56.5 \mu \mathrm{g} / \mathrm{kg}$ for rabbits corresponds to $40 \%$ of that reported for humans [26]. The present study also obtained similar results $(64.1 \pm 7.8 \mu \mathrm{g} / \mathrm{kg})$. For humans, the onset time of neuromuscular blockade during anesthesia induced by nitrous oxide and narcotics was $1.5 \mathrm{~min}$ after an intravenous infusion of rocuronium $(0.6 \mathrm{mg} / \mathrm{kg})$ [27], whereas for rabbits, the onset time during thiopental sodium-induced anesthesia was $0.4 \mathrm{~min}$ after the same dose of rocuronium [25], as we also found, probably because rocuronium doses in rabbits $\left(7 \times \mathrm{ED}_{95}\right)$ are higher than in humans $\left(2 \times \mathrm{ED}_{95}\right)$.

Cardiac output and muscle blood flow determine the onset of a muscle relaxant, but we did not measure these variables. However, onset time and hemodynamic changes are probably minimal because the mean arterial pressure and pulse rates were similar in control and experimental groups. Muscle relaxants with low potency such as rocuronium need to be used in large doses to produce the same effect, which allows a large amount of rocuronium molecules to rapidly move to the neuromuscular junction and elicit faster onset times than past nondepolarizing muscle relaxants [28]. We could not discriminate differences between the two groups because of the rapid onset time of rocuronium.

Administration of clonidine for 3 or 6 weeks did not change the duration of action between the study and control groups. Pharmacodynamically, chronic nondepolarizing muscle relaxants may increase the number of nicotinic receptors [29]. Likewise, clonidine can increase neuromuscular receptors. Leftward shifts of the dose-response curves seems to indicate compensation by catecholamine receptors. Because the longterm administration of clonidine did not affect mean arterial pressure and pulse rate, the clonidine dosage calculated for humans ( $4 \mu \mathrm{g} / \mathrm{kg} /$ day) may be too low to influence the rabbit's cardiovascular system. Clonidine may not eliminate rocuronium or the sample size may be too small to see an effect. Therefore, further study is needed to measure the neuromuscular blocking action of clonidine in larger doses. We could not measure the blood concentration of rocuronium, so it is impossible to define plasma clearance and the volume of distribution.

Megadoses of $\alpha$-2 adrenergic receptor stimulants (imidazole derivatives) such as clonidine or dexmedetomidine (i.e., 32 and $320 \mu \mathrm{g} / \mathrm{kg}$ ) produce muscle relaxation and analgesia [30]. We only used a small clinical dose $(4 \mu \mathrm{g} / \mathrm{kg} /$ day $)$ to prevent observations on analgesic effects.

In conclusion, rocuronium in rabbits pretreated with clonidine for three or six weeks enhanced the effect of muscle relaxation or neuromuscular block, but made no difference on the duration of action between the experimental and control groups.

\section{References}

1. Anavekar SN, Howes LG, Jarrott B, Syrjanen M, Conway EL, Louis WJ. Pharmacokinetics and antihypertensive effects of low dose clonidine during chronic therapy. J Clin Pharmacol 1989; 29: 321-6.

2. Beer GM, Spicher I, Seifert B, Emanuel B, Kompatscher P, Meyer VE. Oral premedication for operations on the face under local anesthesia: a placebo-controlled double-blind trial. Plast Reconstr Surg 2001; 108: 637-43.

3. Nishina K, Mikawa K, Uesugi T, Obara H, Maekawa M, Kamae I, et al. Efficacy of clonidine for prevention of perioperative myocardial ischemia: a critical appraisal and meta-analysis of the literature. Anesthesiology 2002; 96: 323-9.

4. Nakahara T, Akazawa T, Kinoshita Y, Nozaki J. The effect of clonidine on the duration of vecuronium-induced neuromuscular blockade in humans. Masui 1995; 44: 1458-63.

5. Takahashi H, Nishikawa T. Oral clonidine does not alter vecuronium neuromuscular blockade in anaesthetized patients. Can J Anaesth 1995; 42: 511-5.

6. Snider RM, Gerald MC. Noradrenergic-mediated potentiation of acetylcholine release from the phrenic nerve: evidence for presynaptic alpha 1-adrenoceptor involvement. Life Sci 1982; 31: 853-7.

7. Banos J, Badia A, Jane F. Facilitatory action of adrenergic drugs on muscle twitch evoked by nerve stimulation in the curarized rat phrenic hemidiaphragm. Arch Int Pharmacodyn Ther 1988; 293: 219-27.

8. Narimatsu E, Niiya T, Kawamata M, Namiki A. Lack in effects of therapeutic concentrations of dexmedetomidine and clonidine on the neuromuscular blocking action of rocuronium in isolated rat diaphragms. Anesth Analg 2007; 104: 1116-20.

9. Wierda JMKH, De Wit APM, Kuizenga K, Agoston S. Clinical observations on the neuromuscular blocking action of Org 9426, a new steroidal non-depolarizing agent. Br J Anaesth 1990; 64: 521-3.

10. Zhao D, Ren LM, Lu HG, Zhang X. Potentiation by yohimbine of alpha-adrenoceptor-mediated vasoconstriction in response to clonidine in the rabbit ear vein. Eur J Pharmacol 2008; 589: 201-5.

11. Ye WH, Park HS, Chin YJ. The effect of intravenous clonidine pretreatment on blood pressure and heart rate during general anesthesia. Korean J Anesthesiol 1995; 28: 791-5.

12. Laurito CE, Baughman VL, Becker GL, DeSilva TW, Carranza CJ. 
The effectiveness of oral clonidine as a sedative/anxiolytic and as a drug to blunt the hemodynamic responses to laryngoscopy. J Clin Anesth 1991; 3: 186-93.

13. Málek J, Knor J, Kurzová A, Lopourová M. Adverse hemodynamic changes during laparoscopic cholecystectomy and their possible suppression with clonidine premedication. Comparison with intravenous and intramuscular premedication. Rozhl Chir 1999; 78: 286-91.

14. Golub MS, Thananopavarn C, Eggena P, Barrett JD, Sambhi MP. Hormonal and hemodynamic effects of short- and long-term clonidine therapy in patients with mild-to-moderate hypertension. Chest 1983; 83(2 Suppl): 377-9.

15. El-Mas MM, Abdel-Rahman AA. Chronic ethanol-clonidine hemodynamic interaction in telemetered spontaneously hypertensive rats. Vascul Pharmacol 2004; 41: 107-13.

16. Chaouche-Teyara K, Lacolley P, Challande P, Fournier B, Laurent S, Safar M, et al. Effects of clonidine and flesinoxan on blood pressure variability in conscious spontaneously hypertensive rats. J Cardiovasc Pharmacol 1997; 30: 241-4.

17. Talke PO, Caldwell JE, Richardson CA, Kirkegaard-Nielsen H, Stafford M. The effects of dexmedetomidine on neuromuscular blockade in human volunteers. Anesth Analg 1999; 88: 633-9.

18. Berdeaux A, Giudicelli JF. Antihypertensive drugs and baroreceptor reflex control of heart rate and blood pressure. Fundam Clin Pharmacol 1987; 1: 257-82.

19. Kooner JS, Birch R, Frankel HL, Peart WS, Mathias CJ. Hemodynamic and neurohormonal effects of clonidine in patients with preganglionic and postganglionic sympathetic lesions: evidence for a central sympathetic action. Circulation 1991; 84: 75-83.

20. Malta E, McPherson GA, Raper C. Comparison of pre-junctional alpha-adrenoceptors at the neuromuscular junction with vascular post-junctional alpha-receptors in cat skeletal muscle. Br J
Pharmacol 1979; 65: 249-56.

21. Dubocovich ML. Presynaptic alpha-adrenoceptors in the central nervous system. Ann NY Acad Sci 1984; 430: 7-25.

22. Vizi ES. Evidence that catecholamines increase acetylcholine release from neuromuscular junction through stimulation of alpha-1 adrenoceptors. Naunyn Schmiedebergs Arch Pharmacol 1991; 343: 435-8.

23. Ziebell MR, Nirthanan S, Husain SS, Miller KW, Cohen JB. Identification of binding sites in the nicotinic acetylcholine receptor for $[3 \mathrm{H}]$ azietomidate, a photoactivatable general anesthetic. J Biol Chem 2004; 279: 17640-9.

24. Park YJ, Yoo HK, Kim KS, Shim JH. Neuromuscular interactions between mivacurium and rocuronium in rabbits. Korean $\mathrm{J}$ Anesthesiol 1998; 34: 686-93.

25. Kim KS, Shim JC, Jun JH, Lee KH, Chung CW. Rabbits treated with chronic isepamicin are resistant to mivacurium and rocuronium. Anesth Analg 1999; 88: 654-8.

26. Diefenbach C, Nigrovic V, Mellinghoff H, Buzello W. Muscle relaxants. new substances and neuromuscular monitoring. Anaesthesist 1997; 46: 3-13.

27. Foldes FF, Nagashima H, Nguyen HD, Schiller WS, Mason MM, Ohta Y. The neuromuscular effects of Org 9426 in patient receiving balanced anesthesia. Anesthesiology 1991; 75: 191-6.

28. Moore EW, Hunter JM. The new neuromuscular blocking agents: do they offer any advantages? Br J Anaesth 2001; 87: 912-25.

29. Hogue CW Jr, Ward JM, Itani MS, Martyn JA. Tolerance and upregulation of acetylcholine receptors follow chronic infusion of d-tubocurarine. J Appl Physiol 1992; 72: 1326-31.

30. Butelman ER, Woods JH. Effects of clonidine, dexmedetomidine and xylazine on thermal antinociception in rhesus monkeys. J Pharmacol Exp Ther 1993; 264: 762-9. 